\title{
PROFIL GAYA BELAJAR SISWA MELALUI PENDEKATAN KONSTRUKTIVISME DI SMA ANTARTIKA SIDOARJO
}

\author{
Nerva Nur Opticia \\ (SMA Antartika Sidoarjo) \\ nerva.ti2s@gmail.com
}

\begin{abstract}
Understanding of mathematical concepts can be controlled well by the students if teachers can make students tend to be active pembelajaran.Untuk approach is needed to make students more active role in learning. One way that could condition the students play an active role in learning is the constructivism approach. This approach begins with giving problems to the students who ultimately students are expected to find their own way of solving the problem. In order for this study could be run better then the teacher should know the learning styles of each Shiva in order to adapt the way of good teaching. Observed learning styles are visual, auditory, and kinesthetic. The data source of this research in X Mipa 5 SMA Antartika Sidoarjo. Of the class was given a questionnaire about learning styles. Then the results of the questionnaire is reduced so that the two subjects are drawn from every learning style. Having drawn six subjects, administered tests problem solving with the criteria for having written a neat, use of symbols in the plant concept, task writing / composing, sensitivity to issues of artistic and understand about the form of the writing / reading From the results of these tests chrosscheked with interview , From the analysis of the test has been obtained, is obtained as follows. Profiles visual learning style has characteristics include in Lesson prefer casual, like raised his voice while reading, more like a lot of theory in practice, dislikes memorize and like math but weak in the count. Profile auditory learning style has characteristics include the time work on the problems less conscientious, like move their lips while reading, more like learning groups, dislike to memorize, like mathematics. Profile kinesthetic learning style has characteristics include the time learning like more prektek, sometimes like moving his lips while reading, more like learning groups, dislike to memorize, dislike math.
\end{abstract}

Keywords: Learning Styles, Constructivist Approach.

\section{PENDAHULUAN}

Dalam bidang studi matematika, pendekatan pembelajaran atau sering disebut pendekatan pembelajaran matematika sangat penting diterapkan. Dimana pendekatan pembelajaran matematika ini adalah suatu cara yang ditempuh guru dalam pelaksanaan pembelajaran agar konsep yang disajikan dapat diadaptasikan oleh siswa. Dari hal tersebut dapat dikatakan bahwa masing - masing individu akan memilih cara dan gayanya sendiri untuk belajar dan mengajar, namun setidak-tidaknya ada karakteristik tertentu dalam pendekatan pembelajaran tertentu yang khas dibandingkan dengan pendekatan lain. Salah satu contoh pendekatan matematika yang akan dibahas dalam adalah pendekatan konstruktivisme. Cara belajar yang dimiliki siswa sering disebut dengan gaya belajar atau modalitas belajar siswa. Gaya belajar yang dimiliki individu merupakan modal yang dapat digunakan pada saat belajar. Menurut DePorter \& Hernacki (2002: 110-112) Terdapat tiga gaya belajar seseorang yaitu visual (cenderung belajar melalui apa yang mereka lihat), auditorial (belajar melalui apa yang mereka dengar) dan kinestetik (belajar melalui gerak dan sentuhan).

Konstruktivisme adalah proses membangun atau menyusun pengetahuan baru dalam struktur kognitif siswa berdasarkan pengalaman. . (Wina Sanjaya, 2006:264). Teori Konstruktivisme didefinisikan sebagai pembelajaran yang bersifat generatif, yaitu tindakan mencipta sesuatu makna dari apa yang dipelajari. Konstruktivisme sebenarnya adalah salah satu filsafat pengetahuan yang menekankan bahwa pengetahuan kita adalah konstruksi (bentukan) kita sendiri. (Paul Suparno, 1997:18). Menurut teori konstruktivis ini, satu prinsip yang paling penting dalam psikologi pendidikan adalah bahwa guru tidak hanya sekedar memberikan pengetahuan kepada 
siswa. Siswa harus membangun sendiri pengetahuan di dalam benaknya. Guru dapat memberikan kemudahan untuk proses ini, dengan memberi kesempatan siswa untuk menemukan atau menerapkan ide-ide mereka sendiri, dan mengajar siswa menjadi sadar dan secara sadar menggunakan strategi mereka sendiri untuk belajar. Penerapan pendekatan konstruktivisme ini merupakan salah satu solusi yang dapat dilakukan untuk meningkatkan pemahaman siswa terhadap materi relasi dan fungsi dapat meningkatkan pemahaman matematikanya. Dari pengertian - pengertian gaya belajar di atas, disimpulkan bahwa gaya belajar adalah cara yang cenderung dipilih siswa untuk bereaksi dan menggunakan perangsang-perangsang dalam menyerap dan kemudian mengatur serta mengolah informasi pada proses belajar. Terkait dengan hal ini peneliti ingin memberikan gambaran yang signifikan dalam profil gaya belajar siswa yang melalui pendekatan pembelajaran konstruktivisme pada mata pelajaran matematika yang diterapkan terhadap siswa kelas X Mipa 5 di SMA Antartika pada pokok bahasan relasi dan fungsi. Untuk itu peneliti merumuskan judul penelitian pada: "Profil Gaya Belajar Siswa Melalui Pendekatan Konstruktivisme Di SMA Antartika Sidoarjo Tahun Ajaran 20152016"

Berdasarkan latar belakang di atas, fokus penelitian ini adalah Bagaimana profil siswa dengan gaya belajar visual melaui pendekatan konstruktivisme?, Bagaiana profil siswa dengan gaya belajar auditori melalui pendekatan konstruktivisme?, Bagaimana profil siswa dengan gaya belajar kinestetik melalui pendekatan konstruktivisme? yang hasilnya diharapkan dapat bermanfaat khususnya bagi guru matematika sebagai bahan referensi dalam upaya meningkatkan prestasi siswa didalam kelas. Dengan demikian penelitian ini bertujuan untuk mengetahui profil gaya belajar siswa melalui pendekatan konstruktivisme di SMA Antartika Sidoarjo tahun ajaran 2015-2016.

\section{METODE PENELITIAN}

Pendekatan penelitian yang digunakan dalam penelitian ini adalah pendekatan kualitatif. Penelitian ini bertujuan untuk menghasilkan profil gaya belajar siswa melalui pendekatan konstruktivisme pada mata pelajaran matematika. Pada penelitian ini siswa terlebih dahulu diberi angket gaya belajar kemudian dari angket gaya belajar tersebut dianalisis untuk pengambilan sampel dari berbagai jenis gaya belajar diantaranya gaya belajar kinestetik, gaya belajar visual, dan gaya belajar auditori. Kemudian diberi materi matematika dengan menggunakan pendekatan konstruktivisme. Lalu diberi tes matematika yang kemudian guru mengambil 2 sampel dari masingmasing gaya belajar untuk di wawancara yang akan menghasilkan data yang valid.

Pengambilan sampel penelitian dilakukan dengan cara mengambil data angket gaya belajar dari 46 siswa kemudian diambil 2 sampel dari masingmasing gaya belajar secara acak, maka akan didapat enam sampel. Kemudian enam sampel tersebut diberi tes kemampuan pemecahan masalah. Setelah didapatkan hasil dari tes tersebut maka diadakan tes wawancara. Maka data dapat dikatakn valid setelah melalui tiga tahap tersebut.

\section{HASIL DAN PEMBAHASAN}

Hasil penelitian ini dipaparkan dalam tiga analisis. Analisis pertama adalah analisis angket gaya belajar, analisis kedua adalah analisis tes kemampuan pemecahan masalah matematika dan analisis ketiga adalah analisis tes wawanara.

Analisis Angket Gaya Belajar. Untuk mengetahui jenis gaya belajar yang dimiliki oleh siswa kelas $\mathrm{X}$ MIPA 5 di SMA Antartika Sidoarjo, maka dilakukan tes kecerdasan gaya belajar. Hasil tes gaya belajar 
didapat setelah siswa menjawab pertanyaan pada angket gaya belajar siswa. Pada penelitian ini tes tes gaya belajar dilaksanakan pada tanggal 15 Oktober 2015 pada pukul 12.15 WIB sampai 12.30 WIB. Tes gaya belajar ini diberikan pada 46 orang siswa kelas X MIPA 5 di SMA Antartika Sidoarjo. Di analisis angket ini melalui tahap reduksi data yaitu mengambil dua sampel dari setiap gaya belajar.

Analisis Tes Pemecahan Masalah. Pada pengambilan data, subjek diberikan soal tes pemecahan masalah dan mengerjakannya selama 60 menit. Hal ini bertujuan untuk mengamati bagaimana siswa dengan gaya belajar visual, auditory dan kinestetik dalam memecahkan masalah matematika dan juga untuk mengetahui apakah subjek konsisten dengan langkah-langkah pemecahan masalah yang dilakukan sebelumnya. Adapun langkah-langkah yang diamati melalui kriteria setiap gaya belajar yaitu : memiliki tulisan yang rapi, menggunakan simbolsimbol dalam menanam konsep, mengerjakan tugas menulis/ mengarang, kepekaan terhadap masalah artistic, memahami soal berupa tulisan/ bacaan.

Analisis Tes Wawancara. Kegiatan pemberian tes wawancara dilakukan pada subjek penelitian dengan gaya belajar visual, auditory dan kinestetik. Kegiatan pemberian tes pemecahan masalah matematika ini dilaksanakan satu kali. Tes wawancara dilaksanakan pada hari Kamis tanggal 22 Oktober 2015. Pada pengambilan data, subjek diberikan waktu menjawab tes wawancara selama 10 menit.

Pembahasan hasil penelitian berisi tentang hasil analisis data sesuai atau tidaknya dengan fokus penelitian yang telah diajukan oleh peneliti.Dari hasil analisis data yang telah diperoleh di kelas $\mathrm{x}$ mipa 5 SMA Antartika Sidoarjo menunjukkan bahwa profil gaya belajar siswa visual memiliki tulisan yang rapi, suka membaca komik, suka mengeraskan suaranya pada saat membaca, pada saat pelajaran lebih suka santai, banyak teori dan banyak tugas mengarang, suka pelajaran matematika tapi lemah dalam berhitung, tidak suka menghafal, dalam bermusik lebih suka music elektro. Profil gaya belajar siswa auditory memiliki tulisan yang sedikit kurang rapi, suka membaca komik, suka menggerakkan bibir pada saat membaca, pada saat pelajaran lebih suka belajar kelompok, suka pelajaran matematika, tidak suka menghafal, dalam bermusik lebih suka music pop. Profil gaya belajar siswa kinestetik memiliki tulisan yang kurang rapi, suka membaca novel, kadangkadang suka menggerakkan bibir pada saat membaca, pada saat pelajaran lebih suka belajar kelompok, dan banyak praktek, tidak suka pelajaran matematika dan menghafal, dalam bermusik lebih suka music jazz.

Dari hasil penelitian ini dapat disimpulkan bahwa fokus yang diajukan peneliti yaitu "Bagaimana profil siswa dengan gaya belajar visual, auditory, dan kinestetik melaui pendekatan konstruktivisme?" dapat diterima. Dengan demikian profil gaya belajar siswa melalui pendekatan konstriktivisme di SMA Antartika Sidoarjo Tahun Ajaran 2015-2016 dapat meningkatkan proses belajar siswa yang tadinya kurang aktif menjadi lebih aktif dan guru juga lebih bisa memahami siswa dengan mengetahui gaya belajar setiap siswa. Dalam penelitian ini masih banyak kendala dan kekurangan. Salah satu kendalanya adalah kesulitan dalam mencari masalah matematika. Hal ini dikarenakan belum adanya kriteria yang pasti tentang penyusunan soal tes pemecahan masalah. Sehingga dalam menyusun masalah matematika, peneliti berpedoman pada teoriteori yang ada. Kendala lain yang dialami adalah banyaknya siswa yang keberatan untuk menjadi subjek penelitian. Hal ini dikarenakan mereka takut tidak dapat mengerjakan soal yang diberikan karena tidak adanya persiapan. Selain mengalami berbagai kendala, dalam penelitian ini masih terdapat banyak kekurangan. 
Kekurangan lainnya dalam penelitian ini adalah kriteria gaya belajar yang ditentukan peneliti sebagai acuan untuk menentukan kriteria pemecahan masalah matematika berdasarkan hasil tes tulis dan wawancara setiap siswa masih kurang terperinci, sehingga berpengaruh pada penyimpulan tentang profil siswa dengan gaya belajar visual, auditory dan kinestetik.

\section{PENUTUP}

\section{Simpulan}

Berdasarkan pembahasan yang telah diuraikan, maka dapat diambil beberapa kesimpulan tentang profil gaya belajar siswa melalui pendekatan konstruktivisme pada mata pelajaran matematika sebagai berikut:

1. Profil Gaya Belajar Visual Siswa Melalui Pendekatan Konstruktivisme Pada Mata Pelajaran Matematika yaitu: Dalam Pelajaran lebih suka santai, suka mengeraskan suara pada saat membaca, lebih suka banyak teori dari pada praktek, tidak suka menghafal, suka pelajaran matematika tetapi lemah dalam menghitung

2. Profil Gaya Belajar Auditory Siswa Melalui Pendekatan Konstruktivisme Pada Mata Pelajaran Matematika yaitu: Pada saat mengerjakan soal kurang teliti, suka menggerakkan bibir pada saat membaca, lebih suka pembelajaran yang berkelompok, tidak suka menghafal, suka pelajarn matematika

3. Profil Gaya Belajar Kinestetik Siswa Melalui Pendekatan Konstruktivisme Pada Mata Pelajaran Matematika yaitu: Pada saat pembelajaran lebih suka banyak prektek, kadangkadang suka menggerakkan bibir pada saat membaca, lebih suka pembelajaran yang berkelompok, tidak suka menghafal, tidak suka pelajaran matematika.

\section{Saran}

Berdasarkan kesimpulan di atas, maka saran yang dapat peneliti kemukakan adalah sebagai berikut:

1. Para pendidik hendaknya dapat mengenali gaya belajar masing-masing siswa sehingga pendidik dapat mengembangkan pembelajaran dan menentukan model pembelajaran yang sesuai.

2. Sebaiknya para pendidik menjadikan pembelajaran matematika atau bidang studi yang lain menyenangkan, menarik, dan memotivasi dengan pendekatan konstruktivisme yang merupakan strategi pembelajaran dengan paradigma setiap siswa adalah bintang.

3. Sebaiknya, lembaga pendidikan SMA Antartika Sidoarjo Surabaya memfasilitasi guru dengan mengikuti pelatihan-pelatihan tentang gaya belajar dan pendekatan konstruktivisme.

\section{DAFTAR PUSTAKA}

Arikunto, Suharsimi. 2010.Prosedur Penelitian. Jakarta:Rineka Cipta.

DePorter, Bobbi \& Mike Hernacki. (2002). Quantum Learning: Membiasakan Belajar Nyaman dan Menyenangkan. Bandung: Kaifa.

Hamzah, Ali dan Muhlisrarini. 2014. PERENCANAAN DAN STRATEGI PEMBELAJARAN MATEMATIKA. Jakarta:

Rajagrafindo Persada

Gunawan, Adi W. 2006. “Genius Learning Strategi”. Jakarta: Pustaka Utama.

Gunawan, Adi W. 2012. Genius Learning Strategy. Jakarta: PT. Gramedia Pustaka Utama

Moleong, Lexy J. 2005. Metode Penelitian Kualitatif. Bandung: PT Remaja Rosdakarya

Nawawi, Hadari. 2011. Metode Penelitian Bidang Sosial. Yogyakarta: Gadjah Mada University Press.

Sekaran, Uma. 2006. Metodologi Penelitian. Jakarta : Salemba Empat. 
JURNAL BUANA MATEMATIKA. Vol. 6, No. 2, Tahun 2016

Sugiyono. 2003. Metode Penelitian Administrasi.

Bandung: Alfabeta.
Sutopo. 2006. Metode Penelitian Kualitatif, Surakarta: UNS Pres

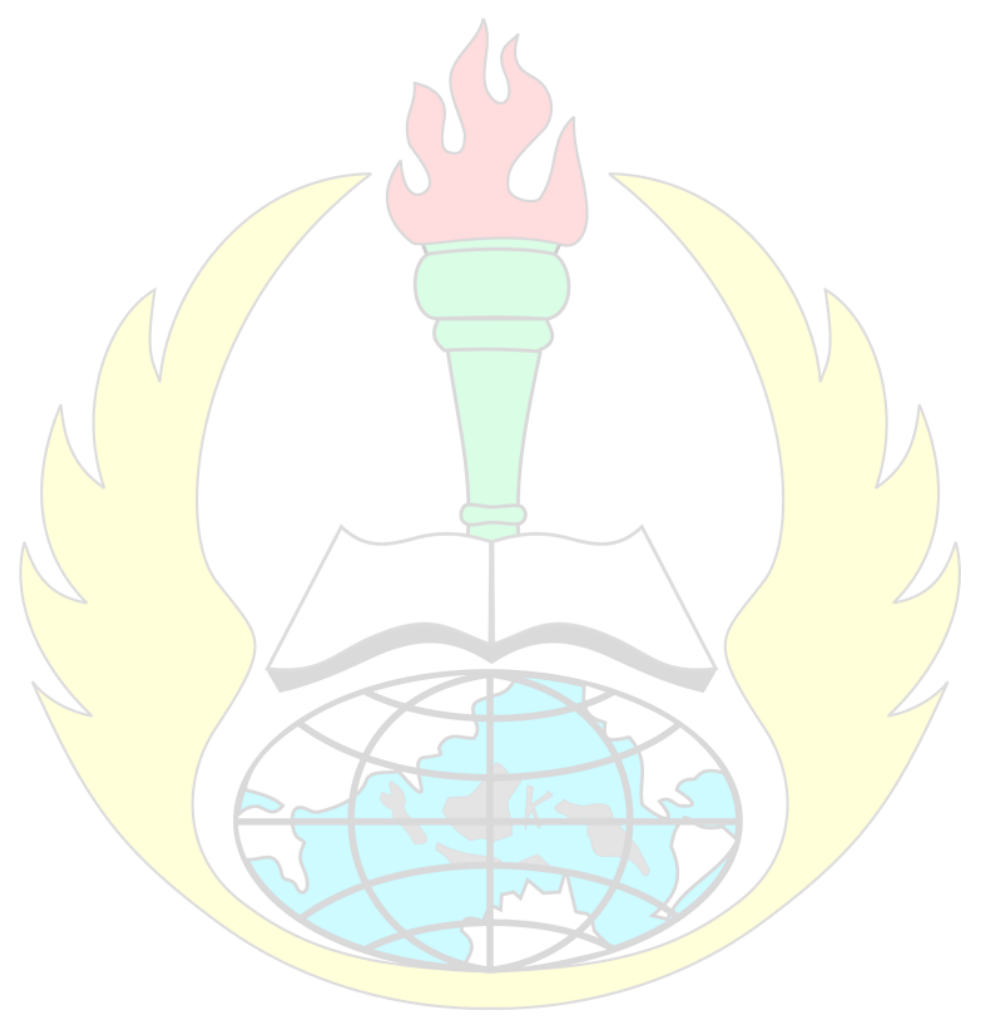

